\title{
Design of Portable Sinks With Foot Pedal Valves For Prevention of Virus Spread in Medan Selayang District
}

\author{
Ivo Andika Hasugian $^{1 *}$, Erwin Sitorus ${ }^{2}$, Ferry Rahmat Bukit ${ }^{3}$, Novrida Hasibuan ${ }^{4}$ \\ ${ }^{1,2}$ Department of Industrial Engineering, Faculty of Engineering, Universitas Sumatera \\ Utara, Medan, Indonesia \\ ${ }^{3}$ Department of Electrical Engineering, Faculty of Engineering, Universitas Sumatera Utara, \\ Medan, Indonesia \\ ${ }^{4}$ Department of Environmental Engineering, Faculty of Engineering, Universitas Sumatera \\ Utara, Medan, Indonesia
}

*Email: ivo.andika@usu.ac.id

\begin{abstract}
At the beginning of 2020, the world was shocked by the outbreak of a new virus, namely a new type of coronavirus (SARS-CoV-2) and the disease is called Coronavirus disease 2019 (COVID-19). Until now this virus is rapidly spreading and research is still ongoing. One of the basic prevention efforts of the corona virus or Covid19 is to diligently wash hands in detail and thoroughly. This is because the corona virus is transmitted through droplets or body fluids that come out when coughing or sneezing. Alfurqon Mosque is one of the places of worship in Medan Selayang District which is a red zone area. It is said to be a red zone because these are areas where residents are positively infected with Covid-19. Based on data from the Medan city health office in April 2020 in this region there were 10 positive patients in treatment. The Alfurqon Mosque has a congregation registered with the STM (Union Please Help) as many as 600 heads of families. So far, this mosque has not provided a place for washing hands specifically accompanied by soap / hand soap. The solution offered is to provide appropriate technology in the form of a hand washing sink that has a 520 liter water tank integrated with a water source pipes and has two sinks accompanied by liquid soap in each sink. This tool uses a foot pedal-style tap valve to turn on and close the water tap so that after washing the hands of the congregation there is no need to touch the tap again.
\end{abstract}

Keyword: Portable Sinks, Foot Pedal Valves, Prevention of Virus Spread

\begin{abstract}
Abstrak
Diawal tahun 2020, dunia digemparkan dengan merebaknya virus baru yaitu coronavirus jenis baru (SARSCoV-2) dan penyakitnya disebut Coronavirus disease 2019 (COVID-19). Diketahui, asal mula virus ini berasal dari Wuhan, Tiongkok. Ditemukan pada akhir Desember tahun 2019. Sampai saat ini virus ini dengan cepat menyebar dan penelitian masih terus berlanjut. Salah satu upaya pencegahan dasar virus corona atau Covid-19 adalah dengan rajin mencuci tangan secara detail dan menyeluruh. Hal ini karena virus corona menular lewat droplet atau cairan tubuh yang keluar saat batuk atau bersin.Masjid Alfurqon adalah salah satu rumah ibadah di Kecamatan Medan Selayang yang merupakan wilayah zona merah. Dikatakan zona merah dikarenakan ini adalah wilayah-wilayah yang terdapat warganya positif terinfeksi covid-19. Berdasarkan data dinas kesehatan kota Medan bulan April 2020 di wilayah ini terdapat 10 orang pasien positif dalam perawatan. Masjid Alfurqon memiliki jamaah yang terdaftar di STM (Serikat Tolong Menolong) sebanyak 600 Kepala Keluarga. Selama ini masjid ini belum menyediakan tempat untuk mencuci tangan khusus yang disertai dengan sabun/hand soap. Solusi yang ditawarkan yaitu dengan memberikan teknologi tepat guna berupa wastafel cuci tangan yang memiliki tangki air 520 liter yang terintegrasi pipa PDAM dan memiliki dua wastafel disertai dengan sabun cair di setiap wastafel. Alat ini menggunakan katup keran model pedal kaki untuk menghidupkan dan menutup keran air sehingga setelah mencuci tangan jamaah tidak perlu menyentuh keran kembali.
\end{abstract}

Kata Kunci: Wastafel Portabel, Katup Pedal Kaki, Pencegahan Penyebaran Virus 


\section{PENDAhuluan}

Masjid Alfurqon merupakan mitra program yang termasuk masjid dengan daya tampung jumlah jamaahnya besar di wilayah Kecamatan Medan Selayang. Jumlah jamaah yang terdaftar di Serikat Tolong Menolong (STM) cukup besar yaitu berjumlah 600 Kepala Keluarga. Jumlah jamaah yang hadir ketika setiap sholat lima waktu rata-rata berjumlah 150 orang dan ketika sholat jumat lebih dari 500 orang. Kecamatan Medan Selayang di golongkan wilayah zona merah karena ada masyarakat yang positif terinfeksi corona. Berdasarkan data dinas kesehatan kota Medan bulan April 2020 di wilayah ini terdapat 10 orang pasien positif dalam perawatan, 35 orang orang dalam pemantauan dan 37 orang tanpa gejala

Setelah virus corona menjadi pandemi, beberapa jamaah meminta ke BKM Al-Furqon untuk di sediakan tempat khusus untuk mencuci tangan yang diletakkan dibagian depan masjid yang disertai sabun cair untuk digunakan sebelum masuk ke masjid. Selama ini jamaah harus berjalan ke kamar mandi dibagian belakang masjid untuk mencuci tangan dan dikarenakan sebagian jamaah telah berwudhu di rumah maka sangat merepotkan untuk ikut mengantri dengan orang yang akan berwudhu hanya untuk mencuci tangan. Salah satu untuk mencegah penyebaran virus corona adalah melalui mencuci tangan secara detail dan menyeluruh, karena virus corona menular lewat droplet atau cairan tubuh yang keluar saat batuk atau bersin. Selain tertular karena menghirup droplet ketika berada dekat dengan orang yang terinfeksi, penularan virus corona juga bisa lewat tangan sebagai media penularan. Sebagai contoh adalah ketika berjabat tangan dengan orang menutupi batuk dengan tangannya, atau ketika Anda menyentuh obyek yang terpapar virus corona.

\section{METODE PELAKSANAAN}

Kegiatan pengabdian kepada masyarakat dilaksanakan di Kelurahan Tanjung Sari Kecamatan Medan Selayang Kota Medan. Kegiatan ini Mei sampai dengan Oktober 2020. Sasaran program ini yaitu Masjid Al-Furqon Kecamatan Medan Selayang Kota Medan.

Langkah-langkah dari pembuatan alat wastafel portable dengan katup pedal kaki untuk pencegahan penyebaran virus di Kecamatan Medan Selayang dapat dilihat pada Gambar 2.1.

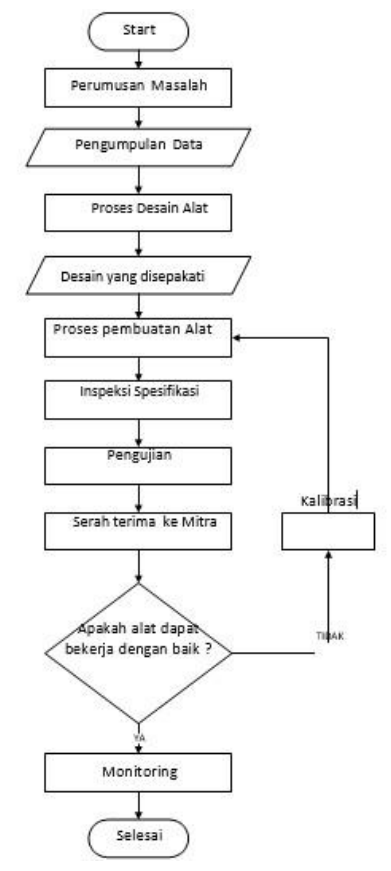

Gambar 2.1. Diagram alir tahapan pembuatan alat wastafel portable dengan katup pedal kaki 


\section{HASIL DAN PEMBAHASAN}

Kegiatan Pengabdian kepada Masyarakat skim Dosen Muda ini dilakukan dengan tahapan kegiatan seperti pada metode pelaksanaan pada diagram alir. Berikut ini merupakan dokumentasi keadaan awal mitra dan dokumentasi setelah penyerahan alat wastafel portable dengan katup pedal kaki kepada mitra Masjid Al-Furqon.

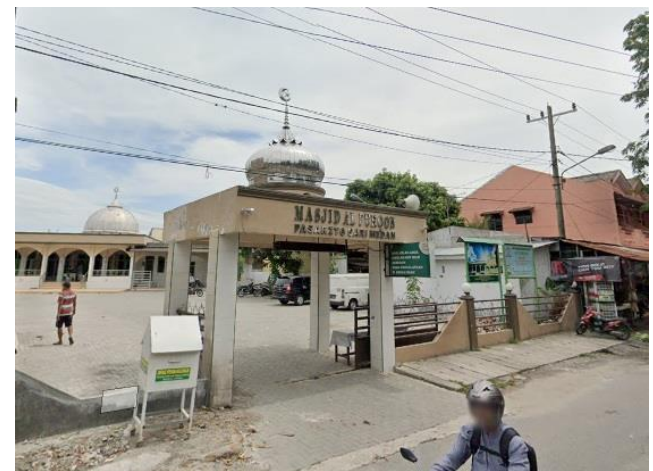

Gambar 3.1. Keadaan Awal Mitra tanpa sarana pencuci tangan.

Masjid Al-Furqon sering mengadakan acara pengajian dengan mendatangkan ustadz berskala nasional dan dihadiri oleh ratusan jamaah yang berasal dari berbagai daerah dan wilayah sekitar masjid.

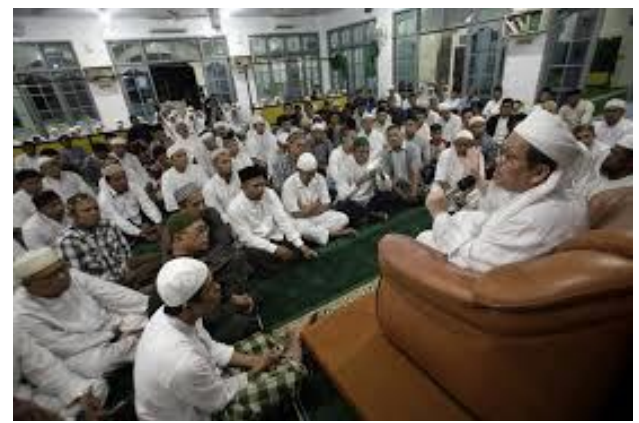

Gambar 3.2. Acara Pengajian Di Masjid Alfurqon

Masjid Al-Furqon memiliki jumlah jamaah yang mengikuti sholat lima waktu dengan total kurang lebih sekitar 100 orang dalam setiap waktu sholat. Jamaah ini berasal dari warga sekitar dan perkantoran di sekitar masjid.

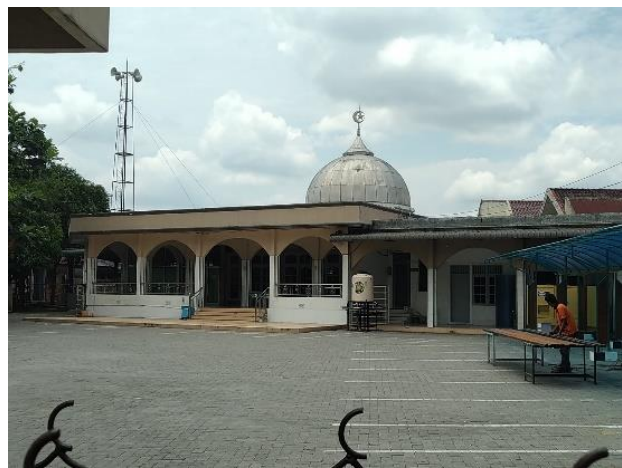

Gambar 3.3. Keadaan Masjid dengan Alat wastafel portabel 
Masjid Al-Furqon selama ini memiliki kamar mandi di bagian belakang bangunan masjid. Selain itu tidak ada tersedia sumber air atau tempat mencuci tangan di sekitar wilayah depan masjid ataupun di pintu masuk masjid.

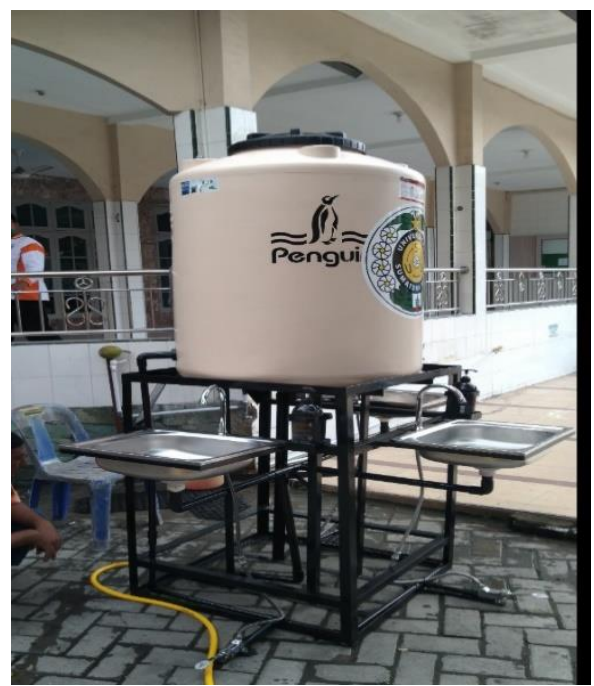

Gambar 3.4. Instalasi pipa buang menuju selokan.

Wastafel Portabel memiliki pipa buang yang terintegrasi ke selokan masjid sehingga air tidak menggenangi halaman masjid. Pipa sumber air untuk tangki juga terintegrasi ke pipa sumber air milik Perusahaan Daerah Air Minum (PDAM). Di dalam tangki terdapat keran otomatis dimana jika air di dalam tangki mencapai tutup tangki maka air akan berhenti sendiri. Selain itu jika air di dalam tangki turun mencapai di bawah pelampung maka keran air dalam tangki akan otomatis hidup.

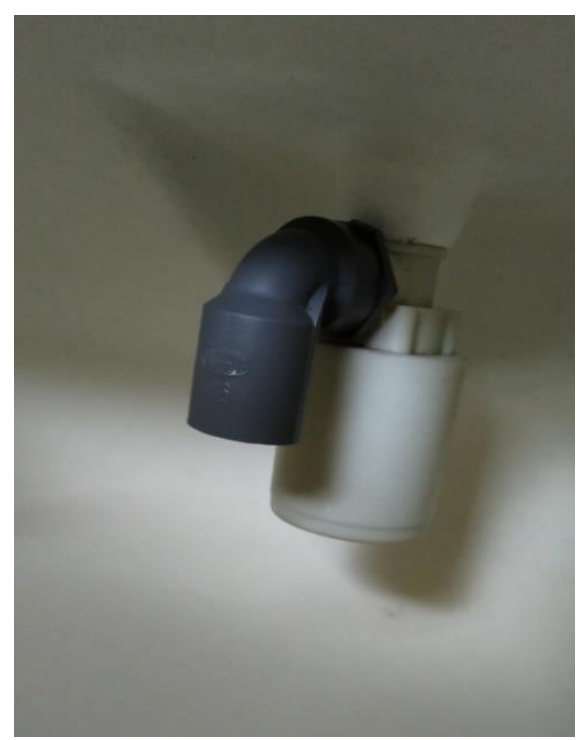

Gambar 3.5. Keran Otomatis di dalam tangka air.

Pemantauan penggunaan fasilitas wastafel portabel dilakukan selama tujuh hari setelah dilakukan serah terima, pemantauan dilakukan pada waktu sholat zuhur dan dari hasil pemantauan didapatkan ada sekitar 40 orang yang melakukan cuci tangan. 


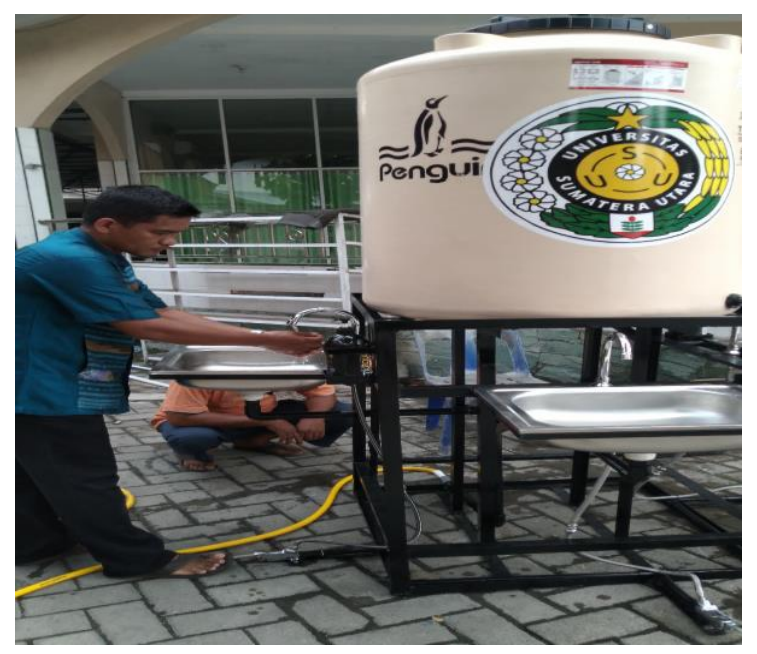

Gambar 3.6. Uji coba penggunaan sarana wastafel portabel di masjid

Dalam proses ujicoba sekitar 50 kali percobaan, terlihat bahwa wastafel portabel di semua bagian yaitu katup pedal kaki, keran otomatis di dalam tangki, penampung sabun cair dan pipa pembuangan tidak ada mengalami masalah.

\section{KESIMPULAN}

Wastafel portabel yang diberikan kepada mitra dapat membantu sebagai sarana pencegahan penyebaran virus Covid-19, alat ini menggunakan pondasi kaki besi siku $40 \mathrm{~mm}$ dengan terintegrasi dengan tangki air Penguin kapasitas 520 Liter. Ukuran wastafel menggunakan rangka besi dengan tinggi 1.1 meter dan memiliki total tinggi berikut tangki air yaitu 2.2 meter. Pedal kaki katup yang di pilih menggunakan material brass kuningan.

\section{UCAPAN TERIMAKASIH}

Tim pengabdian pada masyarakat mengucapkan terima kasih kepada pihak LPPM USU yang telah memberikan dana kepada pengabdian ini. Terima kasih juga kepada pihak mitra yang telah kooperatif di dalam pelaksanaan pengabdian ini

\section{DAFTAR PUSTAKA}

Cross, Nigel. 1996. Engineering Design Methods: Strategies for Product Design. New York: John Wiley and Sons

Manullang, G. 2019. Rancang Bangun Alat Pencuci Tangan Dan pengering tangan Otomatis Dengan Human Module Interface (Hmi) Menggunakan Tft 2.8" Adafruit Berbasis Arduino Mega2560, Bandar Lampung: Universitas Lampung.

Rizki , Hafizur. 2015. Rancang Bangun Sistem Wastafel Otomatis Berbasis Mikrokontroler Atmega8535 Dengan Menggunakan Sensor Fotodioda. Jurnal Fisika Unand Vol.4 No.2

Sukri, Hanifudin. 2019. Perancangan Mesin Cuci Tangan Otomatis dan Higienis Berbasis Kamera. Journal of Science and Technology STT Universitas Trunojoyo Madura.

Wulandari, D. 2008. Sistem Otomatisasi Kran Pencuci Tangan. Semarang. Universitas Diponegoro

Hasugian I, Ingrid F and Wardana K 2020 Analisis Kelayakan Dan Sensitivitas : Studi Kasus UKM Mochi Kecamatan Medan Selayang) Buletin Utama Teknik 15 159-164 